\title{
NATIONAL CINEMAS IN THE GLOBAL ERA
}

\author{
Elizabeth Ezra
}

The concept of national cinemas is not coextensive with cinema itself. In some ways, national cinemas can be said to have existed only since the late silent or early sound era. For the first two or three decades after the birth of cinema, films were not explicitly identified with a particular nation-state; and production companies were international, sending camera operators, films for exhibition and, before long, production subsidiaries around the world. Before the advent of intertitles around 1903, films even 'spoke' local languages, as exhibitors narrated the action for viewers while they watched the images flicker across the screen. But then, in the latter years of that decade, films made in US subsidiaries of French production companies and otherwise indistinguishable from American fare came to be branded as 'foreign' by US companies keen to stake out a domestic market for their own films (Abel, 1999) and, after World War I, when domination of world markets shifted definitively from France to the United States, cinema in other parts of the world was 'nationalised' economically through the introduction of state subsidies and protectionist measures, in large part as a reaction to the emergent hegemony of Hollywood. Finally, through linguistic means, the coming of sound in the late 1920s and early 1930s, before the perfection of dubbing technology, cemented the process of national identification.

Yet national cinema has never been an unproblematic category. The 20th century, with two World Wars, the demise of dynastic and colonial empires, and the end of the Cold War, was a volatile period for the emergence and dissolution of nation-states (and thus of national cinemas). The fall of the Berlin Wall, for example, 
phenomenon, although former East German filmmakers certainly retain a distinctive

voice. And what are the institutional dynamics of a stateless cinema such as that of Palestine? National cinemas are continually in process, evolving with the ebb and flow of nation-states, and with the importance of the nation-state itself as both a geopolitical force and a conceptual entity.

Shifting political landscapes at the sub-national level too can affect a national cinema's status. Apartheid-era South African films have a problematic place within film history, and have been routinely excluded from accounts of African cinema. Since the end of apartheid, South African films have circulated more widely and have attracted much more international interest (although even then, not always without controversy: when Tsotsi won the Academy Award for Best Foreign Language Film in 2006, many in its home country considered the film, which was directed by the white South African Gavin Hood, to be so 'Hollywoodised' as to be almost unrecognisably South African). Then too, political forces can make national cinemas inaccessible altogether. For example, although the first Korean feature film was made in 1923, there are no extant pre-1945 feature films, because these were either destroyed during the Korean War or suppressed during Japanese imperial rule in the early part of the century.

In the 1960s and 1970s, cinema was embraced by many nation-states as a potential tool in the struggle to reassert national autonomy in the wake of decolonisation. The Third Cinema movement, which began in Latin America and was soon invoked by film-makers in Asia and Africa, at once supported these national struggles and asserted an international solidarity among Third World countries (see also Third world and postcolonial cinema, p. 00). In particular, Lusophone African states such as Mozambique and Angola adopted a form of 'guerilla' film-making that attempted to merge Marxist theories with film practice, resulting in a politically committed cinema. Many African 
film-makers, including the Francophone directors Ousmane Sembène from Senegal and Souleymane Cissé from Mali, trained in the USSR, where they learned cinematic techniques from Soviet directors. Similarly, today, many South African film-makers and funding bodies view cinema as an important expression of post-apartheid democratic principles.

However, in the absence of clear principles of political commitment or propaganda, national identity is an elusive category when applied to cinema. Even the most apparently straightforward criteria of the director's nationality or audience preferences are not always helpful. For example, many of the most prominent arthouse films closely identified with a national cinema have been made by foreign nationals, usually by émigré directors and other personnel. The Spaniards Luis Buñuel and Salvador Dalí made what would become the bedrock of 'French' surrealist films in the interwar period; both Charlie Chaplin and Alfred Hitchcock, two of the most celebrated auteurs of American cinema, came from Britain, and many other prominent film-makers working in the post-war era were Europeans who had emigrated to the United States. Many landmark African films of the 1950s and 1960s were made by Africans living abroad, because Africans were barred from making films in the colonial era. In recent times, the Mandarin-language international blockbuster Crouching Tiger, Hidden Dragon (2000) was made by Taiwan-born Ang Lee, who now lives in Connecticut. The concept of national cinema is even less straightforward in the transnational era, when multinational co-productions are becoming increasingly common. If we look to audiences to give the term 'national cinema' meaning, then we are in for incoherence: viewers in West Africa prefer kung-fu films and Bollywood musicals to homegrown fare, and European viewers watch more American films than films produced in their own countries. The fact that South Korean viewers began displaying a preference for domestic films over foreign 
films in the late 1990s has been heralded as a remarkable sign of the unusual robustness of the Korean film industry, rather than as something to be taken for granted (see, for example, Roger Clarke, “The Life and Seoul of the Party,” The Independent, 27 April 2001). All in all, one could be forgiven for wondering if national cinema was merely a short-lived phenomenon, a temporary blip on the world cinematic radar. In the era of globalisation, is it still possible to speak of national cinemas at all, or have they receded, like the withering away of the state that Friedrich Engels so famously predicted some 130 years ago, if in a rather different context (Engels 1878)?

Certainly, and to a large extent, national cinema is a relational, conceptual category, constructed in response to the domination of American cinema, which is often conceived as the only truly globalised, or 'region-free' cinema (like the DVD players that have become a significant means of exhibition). However, the Hollywood/World Cinema dichotomy is challenged by the fact that virtually all cinemas today are deeply hybridised. The widespread adoption of foreign film genres and narrative strategies complicates attempts to associate national cinemas with indigenous traditions or characteristics. For example, Nigerian films often incorporate Bollywood-inspired tales of good versus evil, but they also employ indigenous folkloric motifs and frames of reference. These same traditional elements could be said to bypass the national altogether, as the nation-state structure was imposed in Africa in the colonial era. Palestianian guerilla films of the 1960s and 1970s were inspired generically by American westerns, but they were clearly not inspired by American politics. This hybridisation, moreover, does not merely reflect a one-way stream of influence from Hollywood, as films such as Quentin Tarantino's two-part Kill Bill (2003/4), with its overt references to Southeast Asian martial arts films, suggest (and the flourishing US independent film sector reminds us that 'American 
cinema' is by no means homogeneous). Nor does hybridisation imply a two-way relation between Hollywood and 'the rest', but rather a multi-directional exchange, with different patterns and currents predominating at various times and in various places around the globe. These exchanges are often uneven, but they are uneven in different ways at different times (see Transnational film studies, p. 00).

Films often acquire national status through their settings and storylines, such as the 'heritage' films of Britain and France, or the Bangladeshi film The Clay Bird/Matir Moina/ (Tareque and Catherine Masud, 2002), which, despite being made with French money, is strongly identified with its setting in the Bangladeshi war of independence from Pakistan. But setting is not synonymous with location shooting, especially when other locations are made to stand in for settings depicted on screen for financial reasons (lower production costs or tax breaks), or when sets or special effects are used to conjure up a place. At the same time, particular locales have often been represented on screen long before they come to be associated with the national identity of a body of films, as in the case of Scotland, which was represented in films such as the Ealing comedy Whisky Galore! (Alexander Mackendrick, 1949) well before the first indigenously-funded, full-length Scottish feature film was made, That Sinking Feeling (Bill Forsyth, 1979). Scenes of Africa had been familiar to viewers the world over since the beginning of the 20th century, but it was only in 1955 that what is considered to be the first sub-Saharan African film was made, the short feature Afrique sur Seine (Paulin Soumanou Vieyra), yet this film was shot, and set, in Paris (Sembène's 1965 La Noire de ..., considered to be the first feature-length film made in sub-Saharan Africa, was also set and filmed largely in France). As these and other films demonstrate, a film's national identity is not reducible to its setting. 
Films made in many of the smaller nations rely heavily on financing from other countries, especially Europe. In former Communist countries, privatisation and the demise of state-run structures of production, distribution and exhibition led to a crisis in the film industry. Film-makers were forced to adopt various survival strategies to cope with the new market pressures, including relocating to or collaborating with other European countries (for example, after the collapse of Communism at the end of the 1980s, the Polish director Krzysztof Kieslowski moved his production base to France and financed his films with French and Swiss money). Today, smaller nations often band together, either to pool funds, as in multinational co-productions, or to pool creative resources, as is the case with the Advance Party initiative between Scotland and Denmark, which is producing three films made by different directors set in Glasgow and based on recurring characters, of which the first was Red Road (Andrea Arnold, 2006).

It is not only supra-national identities that problematise the concept of national cinema; these can also be complicated by sub-national affiliations. Indigenous filmmakers in postcolonial or diasporic contexts (such as aboriginal film-makers in Australia, Maori film-makers in New Zealand, and Native American film-makers in the US) sometimes prefer not to be associated with their nominal nation-states because they have oppositional political stances, and/or because they identify more strongly with their regional or tribal affiliation (or sometimes simply for the pragmatic reason that they have been more successful in obtaining financing from regional or other sub-national funding bodies). Québequois cinema, for example, has achieved independent status within the larger body of Canadian cinema, largely because of its linguistic difference from Anglophone cinema, as well as Québec's contested national status. 
Perhaps more than anything else, though, the concept of national cinema is driven by economic factors - domestically by state-funding criteria, and externally by distribution and marketing strategies. Major awards ceremonies such as the Academy Awards and the Cannes Film Festival still use national identity as a primary selection criterion, and these awards have global marketing implications. The controversy surrounding the national identity of the film A Very Long Engagement/Un long dimanche de fiançailles (Jean-Pierre Jeunet, 2004), which prevented it from competing in both the Academy Awards and at Cannes, hinged on the film's financing from a French subsidiary of Warner Bros. Conversely, recent Iranian cinema, though lacking in big box-office potential, has gained a high degree of cachet among international critics and on the arthouse festival circuit, and in these contexts its national identity has served as a modestly effective promotional tool. National identity is also used to market films to diasporic communities around the globe. Unlike many African art films, which are often financed by European backers and circulated globally through film festivals, the indigenous Nigerian film industry (often referred to as Nollywood) produces some 600 films a year, mostly on video, many of which circulate among African communities living abroad (although widespread pirating prevents much of the profit from accruing to the Nigerian production companies). And in India, a growing number of films are aimed directly at diasporic communities. Economic factors nonetheless have undeniable cultural repercussions, and it is perhaps in the diasporic context that a national cinema retains the most affective resonance, contributing to the construction of what Benedict Anderson (1983) called 'imagined communities'.

Ultimately, very few film-makers set out to make a German film or a Taiwanese film or an American film; their films often acquire these identities 
retrospectively, at film festivals and in books and university courses, all of which still rely heavily on the idea of national cinema as an organising principle. Yet this principle not only has an important heuristic function, it also has significant political, economic and affective value, which indicates that, despite the problems with attempts to attribute national identities to otherwise heterogeneous bodies of films, the concept of national cinema is not in danger of disappearing anytime soon.

\section{Selected reading}

Richard Abel, The Red Rooster Scare: Making Cinema American, 1900-1910,

Berkeley, University of California Press, 1999.

Benedict Anderson, Imagined Communities: Reflections on the Origin and Spread of Nationalism, London, Verso, 1983.

Frederick Engels, Anti-Dühring, Moscow, Foreign Languages Publishing House, 1969 (originally published 1878): pp. 302-03.

\section{Further Reading:}

Natasa Durovicovà and Kathleen E. Newman (eds), World Cinemas, Transnational Perspectives, New York and London, Routledge, 2007.

Elizabeth Ezra and Terry Rowden (eds), Transnational Cinema: The Film Reader, London and New York, Routledge, 2006.

Mette Hjort and Scott Mackenzie (eds), Cinema and Nation, London and New York, Routledge, 2000.

Alan Williams (ed.), Film and Nationalism, New Brunswick, NJ, Rutgers University Press, 2002.

Valentina Vitali and Paul Willemen (eds), Theorising National Cinema, London, 
BFI Publishing, 2006. 